\title{
Exploration and Geology of the Attawapiskat kimberlites, James Bay Lowland, Northern Ontario, Canada
}

\author{
Kong, J.M. ${ }^{1}$, Boucher, D.R. ${ }^{1}$, and Scott Smith, B.H. ${ }^{2}$
}

1. Monopros Limited, Waterpark Place, 10 Bay Street, Suite 1510, Toronto, Ontario, Canada, M5J 2R8.

2. Scott-Smith Petrology Inc., 2555 Edgemont, Boulevard, Vancouver, British Columbia, Canada, V7R 2M9.

\section{Introduction}

Diamonds recovered from the Great Lakes area are postulated by many to be glacially transported from the James Bay Lowland. The 1960's work by Selco Mining Corporation and the Ontario Department of Mines led to the detection of 'kimberlitic' indicator minerals in the Moose River Basin, northern Ontario. Further exploration in 1979 by Selco resulted in the discovery of a number of "alnoite-carbonatite" pipes. In 1984, Monopros Limited, a subsidiary of De Beers, started a regional sediment sampling program to the north-northwest of the Selco alnoites. By 1987, the Attawapiskat kimberlite cluster was found. The kimberlites are located near the Attawapiskat River in the James Bay Lowland, $350 \mathrm{~km}$ north of Hearst, $100 \mathrm{~km}$ west of the James Bay coast.

\section{General Geology}

The Attawapiskat kimberlites are overlain by $0-30 \mathrm{~m}$ of glacial and coastal Holocene deposits. The kimberlites intrude through Paleozoic sediments which, based on regional data, may have a thickness of $\sim 250 \mathrm{~m}$. The uppermost limestone sediments are the Silurian reef and bioherm deposits of the Attawapiskat formation. At depth the limestone is underlain by mudstone. The kimberlites are located at the southern flank of the Cape Henrietta Maria Arch which separates the erosional remnants of two adjacent cratonic basins, the Hudson Bay Basin and the Moose River Basin. The basement is part of the Superior Structural Province, the largest Archean craton in the world (3.1 to $2.6 \mathrm{Ga}$.). The accretionary model of the Superior Province by Williams et al. (1992) suggests that these pipes are located on the oldest part of the craton (the protocraton).

\section{Exploration}

Between 1984 to 1986, systematic regional stream sediment sampling from the Kenogami River north to the Ekwan River revealed a 'kimberlitic' indicator mineral suite comprising garnet, chrome diopside, ilmenite and spinel. The Ekwan River was devoid of indicator minerals and provided a good "cut-off". Striking differences exist between the composition of the indicator minerals from this area and from the Moose River basin. These differences suggested a local source in the Attawapiskat River area. The composition of the indicator minerals also imply that the kimberlites sampled material within the diamond window. In 1987, detailed sampling along the Attawapiskat River and its tributaries yielded samples with super abundant kimberlitic indicator mineral grains and a number of kimberlite boulders along a $10 \mathrm{~km}$ stretch of the river.

The boulder discovery prompted an aeromagnetic survey covering $2,900 \mathrm{~km}^{2}$. The survey using combined total field and vertical magnetic gradient measurements identified 33 targets. Detailed ground magnetic surveys defined 16 near surface expressions of kimberlites and 15 deeply buried basement features. Modeling of the magnetic signatures gave sizes ranging from 0.4 ha to 18 ha. Fifteen of the near surface anomalies were normally polarized with a weak negative pole orientated to the north. One anomaly had strong remnant magnetization demonstrating that the kimberlite was emplaced during a period of reversal in the earth's magnetic field. The magnetic signatures for 12 of the anomalies are simple which suggest that each of the pipes was formed by a single event. The signatures for 4 anomalies are complex and may be formed by a composite of separate kimberlites . 
Drilling in 1988 and 1989 proved 16 kimberlite pipes. Results from the drilling show that at least one of the kimberlites is complex (as predicted by magnetics) containing two coalescing intrusions. Three of the 15 other anomalies modeled as basement features were drilled and encountered only limestone to a depth of $200 \mathrm{~m}$ from surface. Subsequently in 1995, 2 small kimberlites were discovered by KWG Resources, Spider Resources and Ashton Mining of Canada Inc. in the northern part of the cluster. Over $100 \mathrm{~kg}$ of core from each of 16 kimberlites were analysed for micro-diamonds and all but one are diamondiferous. Further evaluation work is under consideration.

\section{Geology of the Kimberlites}

The Attawapiskat bodies are all composed of macrocrystic kimberlites (sensu stricto, archetypal) with remarkably uniform groundmass mineralogies usually dominated by carbonate \pm serpentine together with spinel and less common mica, perovskite and monticellite. The carbonate occurs as lath-like grains and/or in the interstitial base. Mantle-derived xenocrysts other than olivine are common, and include ilmenite, garnet, chrome diopside and mica as well as megacrysts of chrome diopside and mica. Local country rock xenoliths are present but not abundant. Overall only minor areas are termed kimberlite breccias. The xenoliths are dominated by varied types of limestone derived from the country rocks. The internal geology of most pipes is fairly simple but some complex multi-intrusion examples are present. These kimberlites are difficult to interpret texturally.

Two main textural rock types are present. The first type is composed of matrix supported olivines set in magmatic groundmasses with uniform to fine irregular segregationary textures. These rocks are thought to be hypabyssal kimberlites (HK). In contrast, the second type is composed of olivines that have clast supported textures. These rocks also have magmaclastic textures (textural classification after Field and Scott Smith, this volume - a). The dominantly round to ovoid magmaclasts (mostly $<1 \mathrm{~cm}$, up to $3 \mathrm{~cm}$ ) have groundmasses as described above and are set in an inter-clast matrix composed mainly of isotropic serpentine \pm carbonate. The presence of carbonate within the magmaclasts and in the inter-clast matrix as well as the paucity of country rock xenoliths are among the features which show that these rocks are not classical tuffisitic kimberlite breccias. The magmaclastic textures fall in the difficult area of petrographic textural overlap between globular segregationary hypabyssal and pyroclastic kimberlite (PK). Some of the rocks may truly reflect these intermediate rock types. However, it is considered that most of this second type is PK. Some of the features which support this conclusion are:

1) the presence of common single olivine grains (usually more abundant than the magmaclasts); some irregular curvilinear magmaclasts; some quenched groundmasses and vesicles within the magmaclasts; a wide range in magmaclast size; sorting with coarser and finer areas and in a few instances better develop bedding (VF-VCK, Field and Scott Smith this volume); normal graded beds up to $1-2 \mathrm{~m}$ thick; overall horizontal fabrics; molding of magmaclasts against xenoliths; concentrations of finer clasts on top of, but not below, large clasts such as xenoliths; the variation in proportion of magmaclasts within one kimberlite unit; and xenoliths of now eroded country rock.

2) the lack of any reaction between the kimberlite and the enclosed limestone xenoliths; and kimberlite selvages on the limestone xenoliths;

Some of the above evidence and other observed features suggest that the final deposition of this material was by primary pyroclastic processes. Although this is an impressive list of features, none of them are as well developed as those observed in some other PK such as the Fort a la Corne pipes (Scott Smith et al., this volume). As well, there are some problems such as possible PK occurring below HK (although the latter could be younger) or PK occurring below possibly in situ limestone. 
Based on the available drilling and the above discussion, it is concluded that the Attawapiskat bodies are composed of both HK and PK but it must be noted that some aspects of the geology of these bodies are not understood. Single pipes are dominated by one of two textural types; the larger bodies usually by PK. The available information for two single pipes suggests steep kimberlite to country rock contacts $\left(>60-75^{\circ}\right)$ and in one of these bodies with a diameter of $\pm 300 \mathrm{~m}$, kimberlite has been recovered down to $250 \mathrm{~m}$. The paucity of xenoliths within the kimberlite shows that the pipes were excavated prior to infilling. It is interesting to consider an emplacement model for the Attawapiskat province in the context of Field and Scott Smith (this volume - b).

\section{Mantle Derived Constituents}

The Attawapiskat kimberlites contain abundant ilmenite and less garnet, chrome diopside and spinel. However, there are exceptions; some kimberlites contain mainly garnet and spinel with rare ilmenites while one kimberlite is garnet poor. The garnets are peridotitic and fall along the lherzolite trend. Both G9 and G10 grains are present but no harzburgitic garnets with very low $\mathrm{CaO}$ content were encountered. Compositionally, the ilmenites have very high $\mathrm{MgO}$ and $\mathrm{Cr}_{2} \mathrm{O}_{3}$ contents, and low $\mathrm{Fe}^{3+} / \mathrm{Fe}^{2+}$ ratios. The chromites include two populations that are usually associated with kimberlites: one with high $\mathrm{Cr}_{2} \mathrm{O}_{3}$ and $\mathrm{TiO}_{2}$ contents, and the second with moderate to high $\mathrm{Cr}_{2} \mathrm{O}_{3}$ and low $\mathrm{TiO}_{2}$ contents. A few chromites have compositions similar to diamond inclusion type grains which together with the presence of G10 garnets indicate that the kimberlites have sampled within the diamond stability field. Trace element analyses on garnets suggest a $37 \mathrm{~mW} / \mathrm{m}^{2}$ geotherm.

\section{Geochronology}

$\mathrm{Rb} / \mathrm{Sr}$ age determinations on phlogopite (C.B. Smith, University of Witwatersrand) gave model ages of 155-170 Ma. for 3 kimberlites and an emplacement age of 156 $\pm 2 \mathrm{Ma}$. for 2 kimberlites. $\mathrm{U} / \mathrm{Pb}$ age determinations on perovskite yielded ages of $179.9 \pm 1.6$ and 179.4 $\pm 2.2 \mathrm{Ma}$. (Geospec Consultants Limited, 1997).

\section{Conclusions}

Stream sediment sampling and geophysics proved to be excellent methods for finding kimberlites in the James Bay Lowland area of northern Ontario. Sixteen kimberlite pipes were found, 15 of which are diamondiferous and evaluation is ongoing. The geotherm for the area was calculated to be 37 $\mathrm{mW} / \mathrm{m}^{2}$. The kimberlites were emplaced between 180-155 Ma. The kimberlites are texturally difficult to interpret but are considered to comprise two types: hypabyssal and pyroclastic kimberlite. The absence of true diatreme-facies kimberlites is significant.

\section{Reference}

Williams, H.R., Stott, G.M., Thurston, P.C., 1992, Part 1: Revolution in the Superior Province, Tectonic Evolution of Ontario: Summary and Synthesis: Geology of Ontario, Ontario Geological Survey, Special Volume 4, Part 2, p.1255-1332. 